MARIANNE E. LIEN; AIDAN DAVISON (2010). Roots, rupture and remembrance: The Tasmanian Lives of Monterey Pine. Journal of Material Culture Vol. 15(2): 1-21 [13591835.

This is an author produced version of the article. The original publication is available at http://www.uk.sagepub.com/journalsProdDesc.nav?prodld=Journal200859

Access to the published version may require journal subscription.

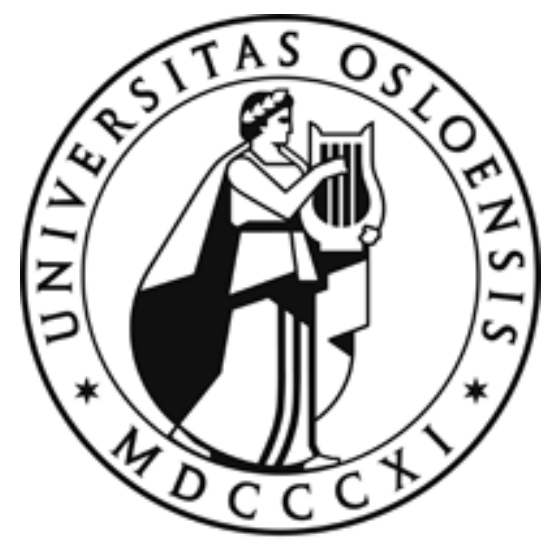




\section{ROOTS, RUPTURE AND REMEMBRANCE}

The Tasmanian Lives of Monterey Pine

- MARIANNE E. LIEN, University of Oslo, Norway

- AIDAN DAVISON, University of Tasmania, Australia

Abstract

Why do certain landscapes become contested sites for claims about identity? We approach landscapes as assemblages of human and non-human elements that reach beyond the confines of their immediate physical and temporal locations. Our empirical focus is a small group of pine trees in a Tasmanian suburb, where remnants of human and non-human migration are inscribed and live on in the landscape and in human memory. We demonstrate how the trees simultaneously invite and resist purification through binaries such as nature and culture, wild and domestic, then and now. The histories and futures of belonging assembled in and through these trees are nothing less than active, idiosyncratic and ongoing processes of differentiation that shed light on the working out of postcolonial, globalizing societies and ecologies.

Key Words: belonging - environmentalism - landscape - Tasmania - trees

In the grounds of the public high school in a suburb called Taroona, a pair of Monterey pine trees (Pinus Radiata) stand together on a rocky point. Nearby, a small group of Monterey pine and Monterey cypress (Cupressus macrocarpa) line the edge of the school's small beach. Prominent in the landscape of the suburb squeezed between wooded hills and the Derwent estuary in Australia's island state, these trees mark the meeting of land and water. After one hundred years of occupancy, the trees' presence in this landscape is being vigorously contested. The trees were planted by George Dixon, whose father, a Yorkshireman, purchased the point and surrounding land in 1894 to create Retreat Farm. Living relics of a colonial aesthetic that preferred imported flora and fauna, these trees have never been passive figures in an exclusively human drama. Old age notwithstanding, they continue to be active participants in the material negotiation of Tasmanian belonging. The tree roots have journeyed deep into a midden whose occupation of this site reaches back 6,000 to 8,000 years into the world of the Mouhenneener people. Today, the trees' Californian origins make them 'matter out of place' on an antipodean foreshore in the process of being restored according to an emerging scientific and moral regime that privileges biological indigeneity. Sanctioned in government legislation and policy, the ecological restoration of Taroona is being led by a voluntary environmental network of local residents, for whom it is self-evident that the 'trees have to go'. But uprooting turns out to be difficult because, as the trees have grown 
FIGURE 1 Monterey pine trees and Monterey cypress line the edge of the high school beach in Taroona, a Tasmanian suburb. The trees are at the heart of a local controversy that concerns both human and non-human belonging. (C) Photo: Aidan Davison.

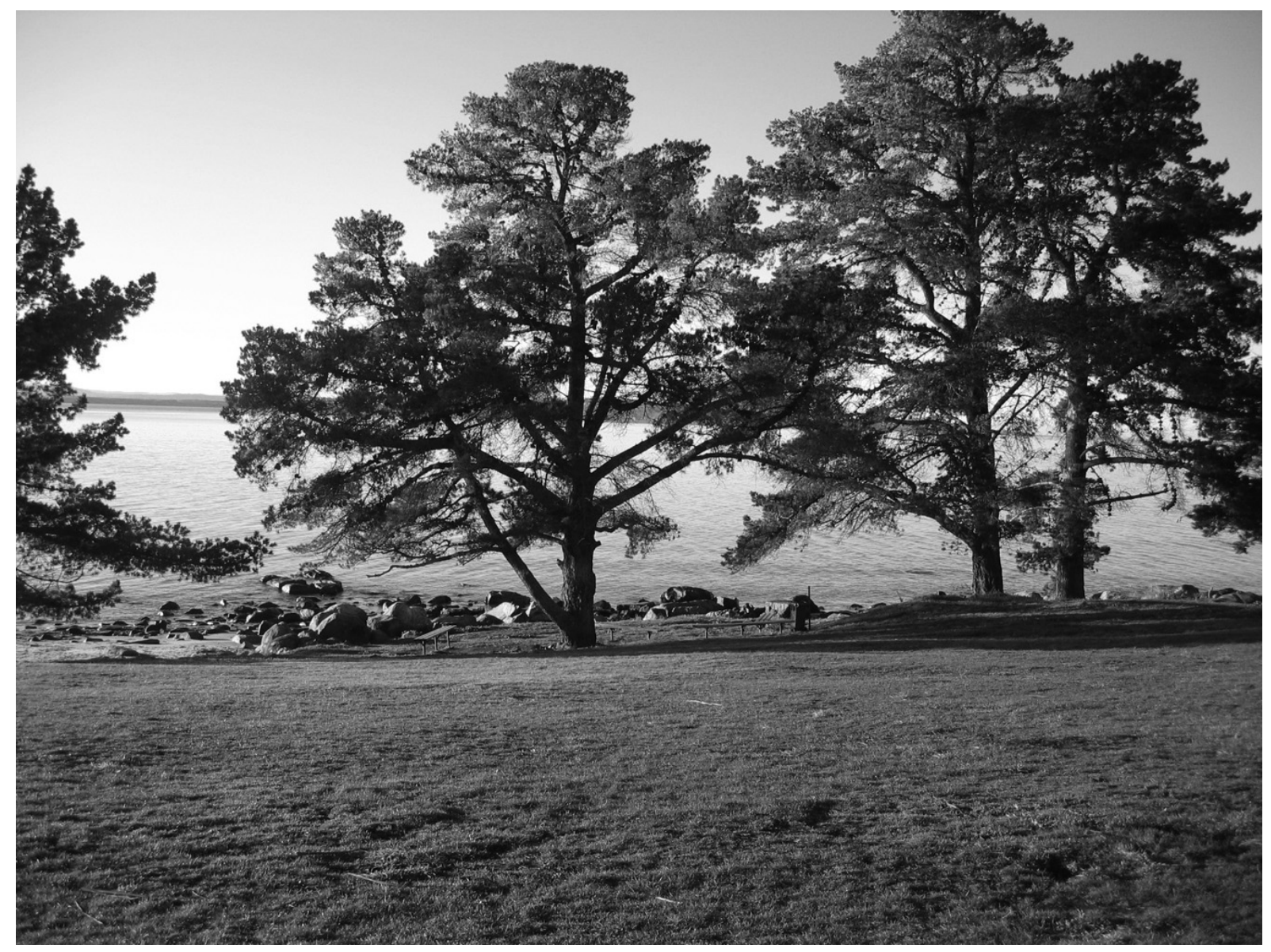

larger, they have also rooted themselves in memories of children-turnedadults who grew up in Taroona. In the dispute that developed around and through these trees, it became apparent that the trees were indivisible from the histories and possible futures that bind this place to wider cultural and ecological dynamics. In this article, we approach the relations sustained through these pine trees as a dynamic and intriguing gathering together of times, places, things and bodies. Our analysis begins from the ontological premise that these tree relations are a part of extensive networks of material and symbolic relations that make human inhabitation of morethan-human worlds possible. These material-semiotic relations work to establish conditions of possibility for human belonging in times and spaces that always transcend them. Tracing the agency of culture and nature encompassed and held together in a Tasmanian assemblage of Monterey pine trees, we identify some key tensions related to migration, memory, roots and rupture in the postcolonial settler society that constitutes Tasmanian belonging today.

\section{BIODIVERSITY AND BELONGING}

Over the last 20 years, the protection of biodiversity has become a foundational goal of global nature conservation (Takacs, 1996; Ridder, 2007). This goal rests upon universalizing scientific discourses in which a distinction between native and non-native species is fundamental (Larson, 2008). According to this discourse, invasive species - a category routinely conflated with that of non-native species - are an important threat to global biodiversity (Van Driesche and Van Driesche, 2000; Simberloff, 2005). Yet the extent to which an ecological distinction between 
native inhabitants and non-native invaders permeates national policies and local vernaculars varies considerably. In Scandinavia, where these concepts have not been part of general discourse about nature, an official classification of native and alien species did not emerge until 2007 (the 2007 Norwegian Black List, published by the Norwegian Biodiversity Information Centre). In the UK and in Germany, this distinction is more conspicuous (Milton, 2000; Gröning and Wolschke-Bulman, 2003; Smout, 2003). However, it is in the Anglophone settler societies of North America, South Africa and Australia that ecological narratives of native inhabitants vs non-native invaders find full expression (e.g. respectively, Robbins, 2004; Comaroff and Comaroff, 2005; Head and Muir, 2004). In these regions, the notion of endemism permeates nature conservation legislation, public discourse and everyday environmental practice.

In Australia, the distinction between native and introduced species is enshrined in legislation. The main federal legislation governing environmental matters is the Environment Protection and Biodiversity Conservation Act 1999. A draft amendment to this legislation relating specifically to invasive species was proposed in 2002, prompting the establishment of a parliamentary inquiry. The 2004 report of this inquiry, Turning Back the Tide - The Invasive Species Challenge described invasive species 'as the second biggest threat to Australia's biodiversity after land clearing'. This threat is claimed to be 'growing daily' and, given recent controls on land clearing, is set to become 'the No. 1 threat to nature in Australia' (Parliament of Australia, 2004: 1-2). In their response to the report, the Federal Government announced the creation of a Defeating the Weed Menace program, designed to increase community awareness of the economic and environmental costs of invasive plants. This initiative was announced in the midst of campaigning for the 2004 federal election in which, as was the case during the 2001 campaign, issues of illegal human immigrants were prominent.

The inquiry defined invasive species as 'non-native flora and fauna that may threaten biodiversity' (Parliament of Australia, 2004: xiii). The inquiry's subsequent report noted in addition 'the ability of native flora and fauna to threaten biodiversity in areas outside their natural range, largely due to human involvement' (Parliament of Australia, 2004: xvi). Their definition resonates with the approach adopted by the World Conservation Union (IUCN) for whom alien species are 'a species, subspecies, or lower taxon occurring outside of its natural range (past or present) and dispersal potential (i.e. outside the range it occupies naturally or could not occupy without direct or indirect introduction or care by humans)' (World Conservation Union, 2000, emphasis added). Similarly, the Federal Department of the Environment (Australian Government, n.d.) asserts that an 'invasive species is a species occurring, as a result of human activities, beyond its accepted normal distribution'. This understanding enables some native species to be regarded and managed as invasive species on the basis that their invasiveness is unnatural, an extrinsic property conferred upon them by human agency (e.g. Pittosporum undulatum in Australia, see Head and Muir, 2004; or Atlantic Salmon in Norway, see Norwegian Black List, Norwegian Biodiversity Information Centre, 2007). The emphasis on geographical origin in Australian conservation discourse masks the fact that many non-native species do not become 'invasive', but may nevertheless be eradicated on the basis of their non-Australian origin (Lien, 2007).

Environmental discourses of nativeness and invasion can be read through the lens of Australian society's colonial and settler heritage and present postcolonial aspirations. It is often noted in settler societies where the majority of residents have ancestral connections to territories elsewhere (and in Australia almost a quarter of the current population was born elsewhere), 
that questions of belonging are associated with ambiguity and anxiety. This is reflected in concerns about sovereignty and border protection (Stratton, 2007), central themes of Australian politics (Seddon, 1997; Perera, 2007). It is in this context that many Australian environmentalists have appealed to the authority of nature, an authority seen to exist beyond the messiness of culture, in an effort to provide conceptual clarity and emotional resolution on questions of Australian belonging. The concept of indigeneity, in particular, has been central to the emergence of a hierarchical logic according to which true or authentic belonging rests on a claim to ancestral lineage (Lien, 2007; Trigger et al., 2008). At the same time, ancestral lineages tying Australians to distant countries have often been represented as denying them 'deep belonging' in their country of birth (Trigger and Mulcock, 2005: 307). Nature becomes an arena for engaging with the authentic Australia, with broad public appeal and strong potential for moral differentiation (see, e.g., Low, 1999). A strong expression of this can be seen in the 2002 Australia Day address of Tim Flannery, one of Australia's most influential environmental scientists and 2006 Australian of the Year:

Certainly, I don't mean to suggest that the European aspects of our history are irrelevant or should be disposed of - only that they reflect us as a people who have not yet developed deep, sustaining roots in the land. Yet, Australia the land, its climate and creatures and plants - is the only thing that we all, uniquely, share in common. It is at once our inheritance, our sustenance, and the only force ubiquitous and powerful enough to craft a truly Australian people. It ought to - and one day will - define us as a people like no other. (Flannery, 2002, emphasis added)

According to Flannery - himself of Irish ancestry - non-indigenous Australians have shallow roots on the Australian continent because most Australians 'still live as people from somewhere else'. Considering the extent of transnational migration during the last two centuries, one may protest that having ancestral links to elsewhere is hardly peculiar to Australians. Many scholars have argued that migrants' cultural appropriation of place is an open-ended process, and one in which transnational trajectories may be the subject of celebration and commemoration rather than an impediment to belonging (Lund, 2007). The roots that Flannery refers to, however, are not imagined as given at birth, as in the case of European genetic kinship. Instead they are seen as something people may develop over time, as their ways of living adapt to the dictates of the land. According to Flannery, the only true belonging available to a multicultural Australia is that which is rooted in the uniqueness and solidarity offered by 'the land, its climate and creatures and plants'. In this way, ecological adaptation to the landscape becomes the timeless variable that distinguishes those who have 'shallow roots' in Australia from those who deserve to be part of the collective unity that constitutes the nation. As the wilderness advocate William Lines (2006: 312ff.) puts it, 'the cause of conservation arises from and fosters a concrete patriotism derived not from abstract discourses about freedom and rights but from living in and breathing a physical, tangible, sunlit Australia.' Rather than seeing troubled senses of belonging in Australia as the inevitable outcome of migration, as Flannery does, we explore the way in which questions of belonging are played out in postcolonial Australian society through material engagements with what is constituted as Australian nature. To do this, we first need to say more about the relation of culture and nature in contemporary environmental discourse. 


\section{ENVIRONMENTALIST NATURES}

The analytical benefits of non-dualistic accounts of nature and culture - accounts of naturecultures - have been described in several areas of the social sciences including anthropology (Descola and Pálsson, 1996; Ingold, 2000), human geography (Whatmore, 2002), science studies (Latour, 2004) and sociology (Franklin, 2006). Such accounts have challenged the dualism which forms the basis of many wilderness-based environmentalist movements. William Cronon (1996) and Bruno Latour (2004) have provided two influential versions of the argument that environmentalists' yearning after pure nature paradoxically reproduces the modernist values they seek to reject. More generally, it has been demonstrated that wilderness is 'saturated, materially and symbolically, with culture' (Head and Muir, 2006: 506). It is timely to inquire Where the Wild Things Are Now, as Cassidy and Mullin (2006) have in the title of their recent collection. A new literature is emerging showing that cities, long thought of as quintessentially 'unnatural' spaces, are thoroughly shaped by nonhuman agencies and populated by non-human bodies and deserve to be thought of as nature as much as wilderness deserves to be thought of as culture (Low, 2003; Davison and Ridder, 2006; Heynen et al., 2006; Hinchcliffe, 2008).

In spite of the vigorous dismantling of conceptual dualisms surrounding nature and culture in the social sciences, the representation of nature as something separate from society continues to permeate much physical science, public policy and vernacular discourse about nature and the environment. This is the case in the biological classification of alien species, which rests on an ontological distinction between human and non-human, (see, e.g., World Conservation Union, 2000). It is also the case among Australian environmentalists, who routinely fall back upon spatial distinctions between natural and artificial (or built) environments when articulating their concerns, and for whom the natural environment constitutes a moral terrain (Lien, 2007; Davison, 2008). The vernacular currency of such distinctions ensures that conceptualizations of the relationship between the natural and the cultural remain 'at the heart of studies of place and landscape' (Tilley, 2006: 19). In our view, ethnographically situated studies of the dynamic gathering together of nature and culture, such as planted trees, provide particularly fruitful points of entry for analysing such processes. This involves attentiveness to the performativity of concepts; to the ways in which any enactment of ideas is simultaneously constituted by and constitutive of the material settings in which it occurs. Bringing into question the assumption that theory and practice are ontologically distinct (Verran, 2001; Davison, 2005), inquiry into specific performances of nature and culture, such as ecological science, resists theoretical abstractions about nature and culture. Narrowing our focus to a small group of Monterey pine trees on a suburban foreshore, we seek to understand how it is that notions of 'the land, its climate and creatures and plants' have come to be such powerful foils against which to establish the terms of Australian belonging. Our approach suggests a modest role for scholarship in the sense that we offer no privileged position from which to subordinate the account of the Other, neither people nor trees. The account of a specific group of trees that we provide belongs to the complex of cultural and ecological relations assembled in and through these trees. Our aim is to narrate these tree relations in a way that does not privilege any particular position, but gently questions all. Let us turn to the Tasmanian Monterey pines.

\section{TANGLED ROOTS IN TASMANIA}

Just as Australian notions of belonging are fraught and ambiguous, so too are Australian discourses about trees (Head and Muir, 2005; Trigger and Mulcock, 2005). This point is vividly 
demonstrated in Tasmania, an island state of about half a million people, where, according to a local author, Richard Flanagan, 'identity has always been fought through the prism of the environment' (cited in Lien, 2007: 103). The environment, in turn, has been fought through the prism of Tasmania's ancient forests and forestry practices (Lester, 2007). Heated debates about the protection of Tasmanian wilderness in general, and old-growth forests in particular, took on national political significance with the successful environmental campaign to stop the damming of the Franklin River in the early 1980s (Hollander, 2006). Since then, the preservation of Tasmania's native, 'oldgrowth' forests has been the founding goal of Tasmania's leading environmentalist organization, The Tasmanian Wilderness Society (Willadsen, 2009). Tasmanian forests have also attracted international attention due to the engagement of transnational environmentalist organizations such as Greenpeace, and the branding of Tasmania as an international wilderness tourist destination.

The pine trees in Taroona are hardly examples of Tasmanian wilderness, yet their role in contests about Tasmanian identity is, in essence, no less significant. Rooted on land that is neither domesticated garden, nor bush reserve, they occupy an intermediate zone between the private and the public, the managed and the wild. The land on which the trees stand is now governed by the public (state) school, and major decisions regarding the trees require some sort of community consensus which, as we shall see, can be difficult to achieve.

A major actor in the unfolding events is the Taroona Environment Network (TEN), a voluntary community group that has operated for over a decade with the aim of restoring the Taroona foreshore and surrounding bushlands through systematic removal of invasive species. They are one of an estimated 60,000 community coastcare groups tending around 1.3 million hectares of Australian coastline (Turnbull and McGauran, 2007: 3). The remarkable growth of these and other landcare groups (such as Bushcare and Rivercare), has been driven by national, state and local policies that devolve responsibility and funding for environmental management to voluntary community groups (Davison and Ridder, 2006). As expressed in countless grant applications, the majority of urban landcare groups are acting upon a general concern to defend what are taken to be the pre-colonial ecologies against weedy invaders. Equipped by an Australian preoccupation with gardening (Head and Muir, 2006), and with gardeners' familiarity with weeding, they seek to 'reclaim' and 'restore' a variety of urban open spaces, from waterways and coastlines to remnant bushland and disused landfills. One could say that they work to rectify the wrongdoings of the past, seeking to resolve non-Aboriginal Australian tensions about belonging through resistance against the spread of non-human invaders of Australia.

For TEN, the decision to cut down the pine trees was initially seen as 'business as usual'. On various occasions, as associated member or occasional supporter, we have joined TEN members who set aside some hours on Sunday afternoons to take part in TEN 'Working Bee' activities. In 2004, for example, and with the help of Conservation Volunteers, a slope of weeds was replanted with native plants. In 2005, the willow trees along the creek in Taroona Park were removed and native shrubs and trees were planted instead. And in 2006, we both took part in poisoning and uprooting the banana passion fruit and South African ivy that almost completely covered a nearby gully. The aim of TEN is to remove such invasive species, and to restore the landscape to what is imagined as its original state, unmarked by the past two centuries' waves of transnational bio-migration. Cutting the pine trees is part of this broader effort, but it is also more than that. 
Under the pine trees, on land that has been part of the high-school grounds for half a century, there is an aboriginal midden. A midden is an aboriginal 'dump': soil interspersed with shell structures, the remains of thousands of meals among people for whom shellfish was a basic food. This midden is one of the few physical remains in Tasmania of the pre-European era, indicating that this particular point offered food and shelter for the Big River Tribe prior to European invasion. The most significant threat to the midden is erosion, especially at this point where waves occasionally wash in. For many years it was assumed that the pines protected the midden by stabilizing it and keeping it in place. The focus of concern about the midden was on humanmade erosion caused by high-school students, who gathered under the trees to seek shelter from the gaze of teachers.

As TEN's vision of landscape restoration includes the preservation of aboriginal heritage, possible threats to the midden had long been an issue of concern to members of the group. For some years, the midden had been covered by boxthorn and bramble, but as these are classified as invasive species, they were removed by TEN, leaving the midden exposed. Once the bramble and boxthorn were gone, however, teenagers gathered there instead, and boots and cigarette butts became a new threat. A fence was set up, but the midden was still exposed. When TEN received financial support for a new project in 2005 that included protection of the midden, they consulted a heritage officer appointed by 'The Tasmanian Aboriginal Land and Sea Council' to receive advice on how best to protect it.

The aboriginal heritage officer's conclusion was quick and clear: the trees would have to go. The reason, he said, was that the pine trees contribute to soil erosion, especially as they are liable to fall over in old age. He had seen this happen on the coast further south where tilted roots of fallen pine trees had exposed the material deep in the midden to erosion from waves. The aboriginal heritage officer's recommendation immediately shifted the attention of TEN from fencing the midden to cutting the trees.

TEN's decision to cut the trees had been discussed by the Taroona High School association, which, after some discussion, consented to the tree cutting. However, as the issue had caused some debate in the association, and because community consultation was seen as important, TEN decided to arrange a public meeting at the high school. They had invited the aboriginal heritage officer to talk about the site, and had planned to take the participants outside to show them the spot and, hopefully, through information, achieve full support for the removal of the trees. But when the meeting took place on 3 December 2005, things did not go as planned. The meeting became something of a battleground, with questions and answers becoming increasingly combative and hostile. Rather than reaching consensus, an ideological rift was exposed. Many local residents simply did not want the pine trees to be removed, and they were prepared to fight for them. The TEN organizers were disappointed because their voluntary efforts for the ecological common good were clearly not appreciated by all. Advocates for the trees were disappointed because their appreciation of the landscape seemed relegated to a past best erased and forgotten. In the days after the meeting, Taroona's pine trees became the focus of heated debate in Hobart's daily newspaper, The Mercury, with a story on the dispute eliciting 'letters to the editor' from as far away as Western Australia. In Taroona, the dispute took the form of anonymous fliers in mailboxes accusing TEN of working against the community. When we spoke to people about the dispute a few months later, there were stories of anger, sadness, distrust, and of people having lost weight due to emotional stress. It was clear that, for many, these feelings lingered on. 


\section{'THE RIGHT THING TO DO'}

What is this dispute all about? Let us first turn to the environmental volunteers. For the core members of TEN, many of whom did not grow up in Taroona, this dispute is primarily about restoring the landscape through the removal of introduced plants. For Ben, a key member of TEN since its early years, and his friend Cindy, removing exotic trees such as pine is a perfectly normal thing to do. They did it when they grew up on mainland Australia, now they do it in Tasmania. Like many Australian environmentalists, Cindy and Ben share a sophisticated understanding of biological processes provided by university education in the life sciences. Their aim is to protect biodiversity, but there is also an aesthetic dimension. Cindy puts it this way:

As an Australian, you are filled with images of what Australian landscape looks like. You learn to know what a native landscape is, and to appreciate the changes that happen when, for instance, undertaking a project of weeding and replanting.

Ben adds that this has to do with a set of values that affect the way you see things. And as we talk, it becomes clear that the interviewer's inclination to sort out different types of motives, ecological vs aesthetic vs moral, does not lead anywhere. The question about whether pines trees belong in Australia gets to the heart of the way in which they relate to the landscape, and to be Australian. The issue at stake is one of ethics, aesthetics and ecology, all together.

A similar tangle of morality, beauty and truth characterized engagements with the landscape in the colonial era. Planted by Mr Dixon around the end of the Australian colonial era in 1901, the pine trees are a living reminder of the vigorous acclimatization efforts of settlers at the time (Lien, 2004; Franklin, 2006). Tasmanian parks and gardens are still full of exotic trees, some of European origin, some native to other parts of the British colonial empire, such as the Californian Monterey pine. Such trees, taken from one corner of the New World to another, remind us of the multidirectionality and extent of colonial flows of plants and animals (Tyrrell, 1999). Monterey pine was introduced to Australia in the 1850s, probably via American miners taking part in the Australian gold rush. In 1857, it appeared in Sydney's Botanical Gardens, with commercial planting of the pine for timber and paper pulp beginning in 1916 (New South Wales Department of Primary Industries, 2008).

Mr Dixon's motive in planting pines on the margins of his farm was hardly commercial. Perhaps they were to commemorate the memory of his mother, Emma, who fell under the wheel of a cart in December 1900 (Dixon, 1986: 298-301). The choice of location on a waterfront cleared of gum trees over 50 years earlier, certainly suggests that this young man's decision was partly aesthetic, a way of enhancing the point where the land meets sea, creating a highly visible shape against the horizon. The trees have done the job well. One woman who today protests against the cutting of trees talks about her morning walks along the foreshore, and vividly describes the beauty of the pine trees in the morning, when the sun shines behind them from a particular angle, casting its distinctive pattern of light and shade over the point.

But why Monterey pine? Could not a native eucalypt have achieved the same effect? Visually it might, but its potential to distinguish and differentiate would most likely have been different. In light of accounts from the time when the pine trees were seedlings, we may imagine that the pine trees served also to differentiate farmland from bushland, given that the small settlement of Taroona was then separated from Hobart by dense eucalypt forest. The choice of an exotic species might also have been a way of aligning with the taste of the landholding class, or to 
differentiate the Dixon farm from less affluent farms in a state which struggled to get rid of what historians refer to as the 'convict stain'.

While Mr Dixon's intentions remain opaque, those of the TEN volunteers are more readily available to us. If the pine trees allowed forms of cultural and environmental differentiation in the past, the cutting of the pine trees certainly allows for processes of differentiation today. Cindy's earlier comment reflects a vision of the Australian landscape as something apart, differentiated from other landscapes. Her view of nature assumes distinct botanical features as an intrinsic feature of various landscapes around the world. This view is congruent with contemporary biodiversity discourse, according to which different regions support unique ecological features. The cutting of the pine trees thus becomes a small act of purification, or, as we have argued elsewhere, an example of environmental utopianism (Lien, 2007). For some opponents, it is precisely such purifying efforts that reveal Australian environmentalism's troubling ideological resemblance. Accusations of 'eco-fascism' and 'species cleansing' have been used to posit conceptual parallels between contemporary environmentalism and 20th-century fascism and nazism (Hage, 1998).

To many environmentalists, however, including those involved in TEN, such accusations would seem deeply unfair. First, their purifying effort is strictly concerned with what is taken to be the domain of nature. Australia's national environmentalist political party, the Greens, for instance, has been strongly critical of the Federal Government policy of mandatory detention of illegal immigrants, calling for a more generous reception of refugees. Environmentalist justification of the need for pure nature thus presupposes an absolute separation of society and nature (Davison, 2008). Second, many environmentalists consider accusations of eco-fascism to be absurd as their rationale for engaging in landscape restoration is, in their view, not political, but is first and foremost scientific. As such, their efforts are rooted in a foundational logic which attributes to science an ontological primacy that establishes it as both separate from, and superior to, the inherently messy political domain (Verran, 2001; Latour, 2004). According to this perspective, the 'right thing to do' with contested natures such as the pine trees is a question ideally settled by scientific logic which, in itself, remains apolitical and universal.

Ben, who works in ecological modelling, explains that pine trees change the chemistry of the soil. This is because the needles make the soil acidic and prevent other trees and bushes from growing underneath the pine. He also explains that when the trees get blown over, the roots are going to take a significant part of the midden with them and expose the rest to various threats such as storm water run-off, waves at high tide and erosion caused by people walking over it. Ben's argument incorporates a temporal and dynamic understanding of the assemblage of roots, water, people and midden. As long as the trees stand upright, their roots are nurtured by the midden material that they also protect, by holding it in place. But since the pine trees have such a short life span compared to the midden, the death of a tree could be the end of the midden as well. By focusing strictly on the relations between material elements of the assemblage surrounding the pine trees, Ben differentiates science from local politics in a way that enables him to feel certain that cutting the pine trees will be the 'right thing to do'. However, as we shall see, the scientific approach is not the only approach one may take on this issue. 


\section{INSCRIBED MEMORIES}

We have explained how the trees came, and why some people believe they 'have to go', but why are they the focus of so much emotional engagement? Let us bring in some other voices from the neighbourhood.

Jenny, like many other residents, has fond memories of teenage years in Taroona. She lives in a house on the foreshore overlooking the sea, about 10 minutes walk from Taroona High School. A member of TEN, and sympathetic to the environmental movement, she has recently chosen to speak up against what she sees as TEN's part in the destruction of the aesthetic beauty of Taroona, and a lack of respect for the diversity of opinion about Taroona's landscape. Jenny sees the pine trees as iconic landmarks in the community, emblematic of 20th-century culture. She explains that when the trees were planted, Taroona was a farming community, and that the pine trees are the only relics left from that era. More than this, the trees provide continuity in her own biography:

I sat under there during my childhood. I have spent time sitting under those trees with my children. And if they survive another 15-20 years I could sit under them with my grandchildren.

She goes on to explain how she values the trees as much as she does the midden:

It is layered in complexities, you know, there is the midden, there are the trees, and then within the high school there are some of the old orchard trees. And then there is the grassy landscape... There is nowhere that I can think of along this whole foreshore where there is a ... lawn going right down to the seaside... That is part of the seaside culture that happened in Taroona in the 1950s. And I love it for that. It is an important part of our history too.

Just as cutting pine trees allows Cindy a sharper differentiation of her image of a unique Australian landscape, Jenny's view also incorporates the trees' ability to differentiate. What is significant for Jenny, however, is not the pristine, non-human landscape, but rather its multilayered complexities through which she, and others, may differentiate particular historical moments and entanglements, human and non-human, inscribed in their local surroundings.

With an academic degree in environmental planning, Jenny is more articulate on issues of cultural meaning than many others, but her views reflect a general sense of disquiet about emerging nativist environmental norms. She was sad when the willows in the park were chopped down, and found little comfort in subsequent replanting of native trees and grasses, which she described as resulting in 'a graveyard of plastic', in reference to the plastic staked around seedlings as protection from weeds. But this dispute is also about a sense of power and belonging: about whose memories, whose heritage and whose aesthetics get to be inscribed in the landscape. The newspaper debate revealed that Jenny was not alone in holding concerns about environmentalist disregard for recent cultural history. One of the letters to the editor describes nature rehabilitation in Taroona as 'vandalism being perpetrated ... in the name of conservation', and continues:

This kind of thing is going on all around our suburban coastline. Trees that provide much- needed shade in summer, which add beauty and balance to the coastal scene, and not least, in this context, help to bind the soil against the ever-increasing effects of the 
rising tide, are being destroyed, either in the search of some politically correct ideas of returning our civilisation to its 'pre-settlement state' ('native trees good, all other trees bad') or, as in this case, to preserve some artefact perceived to have cultural value. (Ian Milne, Seven Mile Beach, Letters on Sunday, The Mercury, 1 January 2006)

The rift created by the presence of the pine trees concerns not only whether or not culture should play a part in restoration activities, but the question of whose culture is at stake. It is, as the opponents of felling the pines would put it, about whether it must take thousands years of being literally 'rooted' on an isolated island to have one's cultural heritage protected, or whether a century might be enough. It is about the tensions between the idea that cultures - and landscapes - should be distinct, isolated units, and the idea that culture - or landscape - could sometimes be the incidental, haphazard outcome of connections between people and places throughout history.

Although the aboriginal heritage officer was clear about the need to remove the trees, debate about the trees cannot be neatly ordered according to identification or affiliations with the Tasmanian Aboriginal community. First, as the need to protect the midden was generally accepted, it was the pine trees, rather than the midden, that became the focus of debate. Second, Tasmanian Aboriginals would take different positions. As an outsider to Taroona, Jim Everett, a writer and spokesperson for the aboriginal community, was unaware of the specific conflict at issue here, but explained that this type of conflict was familiar to him. When asked how he feels about trees such as pine, he replied:

Everett: I see them as a pest. For me they hold the memories of the colonial past, I see the pine trees and I think of the British, and then I want to cut [the pine trees] down. Same with the willows. They are dangerous trees.

Interviewer: Why?

Everett: They drink a lot of water and clog the waterways. I would cut them down.

He explains that it is not only what these trees represent, but also what they do, and that these go together (for a nuanced description of a related topic, see Everett and Kimberley, 2006). Others feel that European trees should be allowed to stay, precisely because they are relics of a colonial era which one should not forget. Such different views reflect a dynamic and heterogeneous discourse in aboriginal communities across Australia. Based on a broad range of studies of aboriginal appropriations of exotic plants and animals in Australia, anthropologist David Trigger (2008) concludes that there appears to be 'a form of intellectual generosity evident in aboriginal acknowledgement of the sentience of exotic species' (p. 642). He further suggests that 'this form of creative cultural resilience is a significant aspect of the reproduction of Aboriginal “indigeneity” over time' (p. 642). 
FIGURE 2 'Graveyard in plastic': cleared and carefully replanted with native seedlings by the Taroona Environmental Network, this field is referred to by some as a 'graveyard in plastic'.

(c) Photo: Marianne E. Lien.

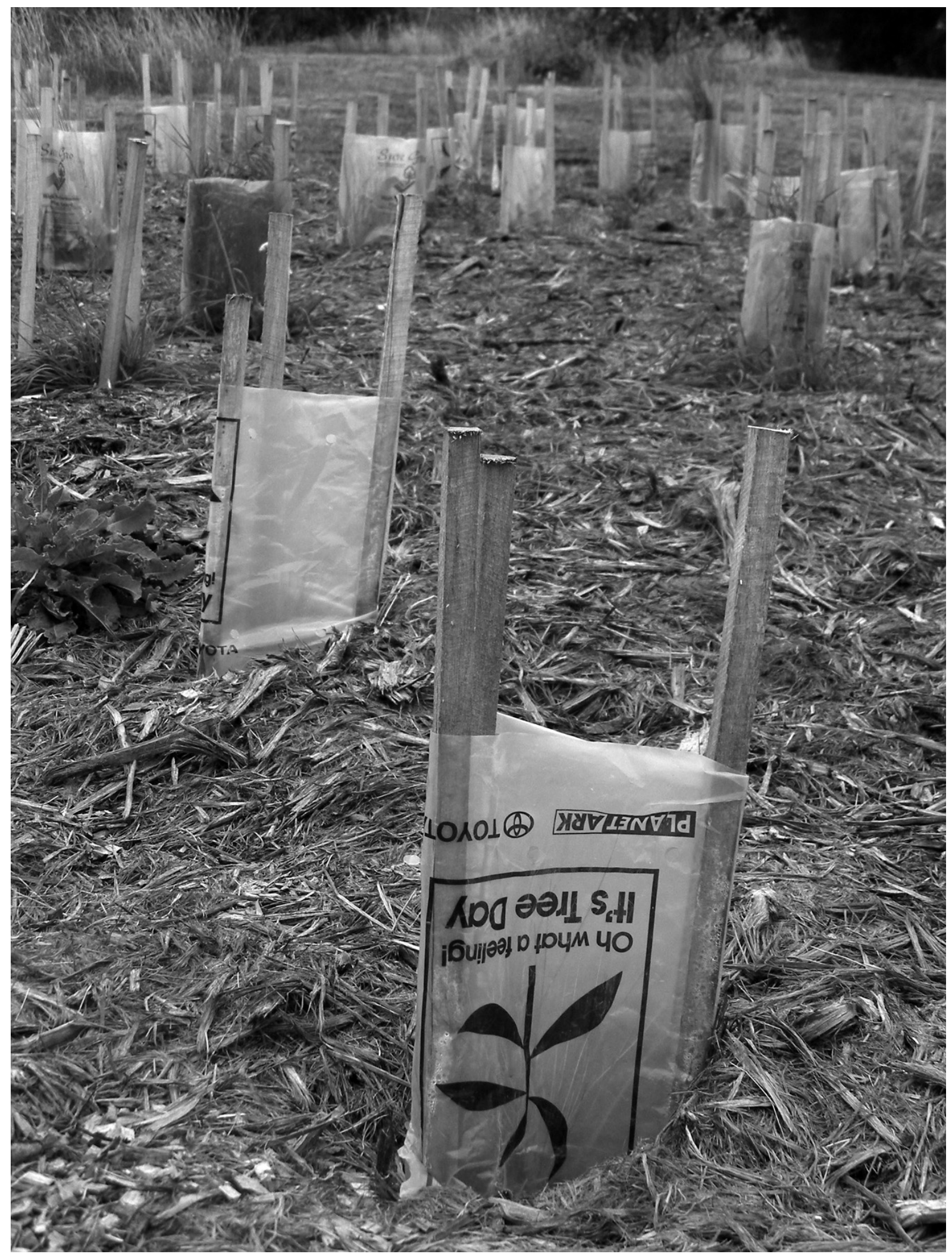


FIGURE 3 The two Pinus Radiata trees at the centre of the local controversy stand in the background, atop a midden and on a small point in front of the Taroona High School. In the foreground are seedlings of local native species, protected by wooden stakes, planted by the Taroona Environment Network in 2006. (C) Photo: Aidan Davison.

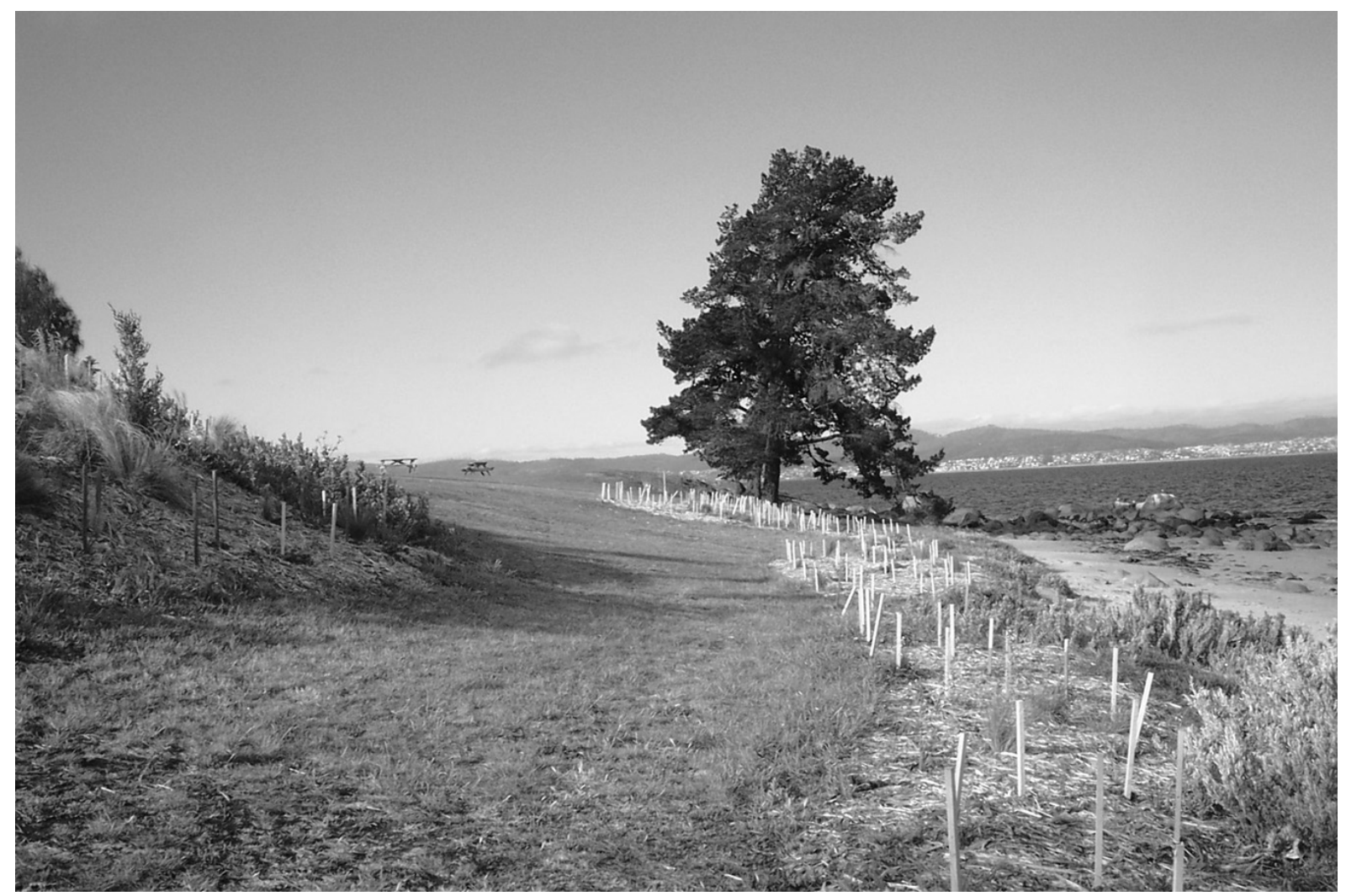

\section{TAKING TREES SERIOUSLY}

The protection of cultural heritage depends upon a fairly clear distinction between artefacts and waste. The boundaries shift over time, but some sort of distinction remains as a necessary condition of cultural heritage practice (De Silvey, 2006). A similar distinction underlies nature conservation. In Australia today, this distinction draws legitimacy from scientific discourse on biodiversity, which in turn implies a distinction between native and invasive species (Franklin, 2006; Lien, 2007). Consequently, from the perspective of current nature conservation policies, pine trees like those in Taroona represent a form of 'environmental waste'. But unlike other 'weeds', the Monterey pines on the Taroona foreshore are also potentially cultural heritage objects. As physical manifestations of a bygone botanical aesthetics and as a marker of civilization in a landscape taken by 19th-century settlers to be a vacuum needing to be filled with meaning, Taroona's pines trees constitute an ambiguous entity. They may, as we have seen, be thought of as either artefacts or waste, but they cannot possibly be both artefacts and waste at the same time. Hence, the debate about the future of these trees becomes a struggle to define the categories of artefact and waste, their contents and their boundaries. But the pine trees are more than relics of a past age. These long-lived mortals are, as Jones and Cloke (2002) put it, 'continually unfolding in the contexts of specific places, in which meanings will arise from particular interactions between different assemblages of social, cultural and natural elements' (p. 1). Their roots find their way between cigarette butts and broken shells as they infiltrate the midden, an entity itself entangled in the tensions between artefact and waste through its historical re-classification from a local rubbish dump in a distant past to a cultural relic of the present. Caitlin de Silvey (2006) has argued that an approach that sees artefacts as a process, 
rather than a stable entity, might be better able to address some of the more ambiguous aspects of material presence and decay. She suggests that some objects could then be seen as 'neither artefact or ecofact, but both - a dynamic entity that is entangled in both cultural and natural processes, part of an admixture of waste and life, of decadence and vitality' (p. 324). De Silvey reminds us that the permanence of objects, like the timelessness of landscape, is only achieved momentarily. What appears timeless, such as the artefacts in the display gallery of museums or a carefully restored example of native landscape, is indeed a fragile achievement, and often the result of human intervention.

Through the Tasmanian lives of a small group of Monterey pine trees, we have followed some tangled traces of belonging running through a complex assemblage of human and non-human elements. These relational connections reach far beyond the spatial and temporal confinement within which the trees have taken root. The trees' contested presence involves the continual unfolding of naturecultural relations in which meanings 'arise from particular interactions between different assemblages of social, cultural and natural' (Jones and Cloke, 2002: 1). Taking pine trees seriously as dynamic, living entities of culture and ecology has called for a consideration of the trees' inherent propensity to grow, upwards, downwards and sideways, to bundle many times and places within their apparent fixity, and to draw to themselves people, shells, shadows and wind-song.

The pine seeds' propensity to sprout and the seedlings' propensity to grow tall in temperate climates converged with human ambitions in initiating their journey to Tasmania. Later, their distant origins saw their presence in Tasmanian soil contested. At the same time, their lack of reproductive endeavour in this soil allowed them to become distinct visual landmarks, and to remain ignored by early efforts to protect native ecologies against invasion. Having begun life and reached maturity on a farm, these trees found themselves in school grounds where their broad trunks and wide canopies provided shelter from the sun and from the gaze of teachers. Adolescents congregating beneath the canopies contributed to erosion of the midden, eventually attracting the attention of TEN. The subsequent conflict saw environmentalist aesthetics, with science on their side, juxtaposed with fidelity to the trees born out of the life-long relationships of many local residents. Paradoxically, the key 'witness' in this dispute, the aboriginal heritage officer, had never lived in Taroona. Although biological science had assumed authority to define the native, pre-colonial ecology of Taroona, the aboriginal heritage officer spoke with the authority of the only person involved who had ancestry to precolonial Tasmania.

Far from being passive objects onto which human ambitions and desires are projected, these pine trees have participated in a course of events in which the outcome is far from given at the outset, and far from over. The trees are entangled in relations with their human and nonhuman surroundings in ways that create geographies of proximity and distance bearing little resemblance to the geometry of modern maps. In the temporal arc of these trees from seed to toppled skeleton, many times are brought together, with the interleaving of midden and roots giving material form to the interleaving of memories, dreams and visions. As a result, the fate of what appears at first to be a few insignificant pine trees attains a power that both divides and unites, making a small rocky point on the Taroona foreshore a highly contested site for claims about Tasmanian identity. 


\section{Acknowledgments}

The authors would like to thank the Taroona Environmental Network and other residents of Taroona and its surrounds for generously sharing their time, their working bees and their views on Tasmanian nature and culture. We also thank fellow participants in the network 'Performing Nature at the World's Ends' (PN@WE) for inspiration and for providing opportunities to meet. Marianne Lien acknowledges the support of the Department of Social Anthropology, University of Oslo that made fieldwork possible. Aidan Davison acknowledges the support of the Australian Research Council (Grant DP0987099).

\section{References}

Australian Government, Department of the Environment, Water, Heritage and the Arts (n.d.) 'Invasive Species'. URL (consulted 12 Nov. 2007): http://www.environment.gov.au/biodiversity/invasive/

Cassidy, Rebecca and Mullin, Molly (2006) Where the Wild Things Are Now: Domestication Reconsidered. Oxford: Berg.

Comaroff, Jean and Comaroff, John (2005) 'Naturing the Nation: Aliens, Apocalypse, and the Postcolonial State', in Thomas. B. Hansen and Finn Stepputat (eds) Sovereign Bodies: Citizens, Migrants and States in the Postcolonial World, pp. 120-47. Princeton, NJ: Princeton University Press.

Cronon, William (1996) 'The Trouble with Wilderness, or Getting Back to the Wrong Nature', in William Cronon (ed.) Uncommon Ground; Rethinking the Human Place in Nature, pp. 69-113. New York: W.W. Norton.

Davison, Aidan (2005) 'Australian Suburban Imaginaries of Nature: Towards a Prospective History', Australian Humanities Review 37, December. URL (consulted 8 Feb.

2010): http://www.australianhumanitiesreview.org/archive/Issue-December-2005/davison.html

Davison, Aidan (2008) 'The Trouble with Nature: Ambivalence in the Lives of Urban Australian Environmentalists', Geoforum 39(3): 1284-95.

Davison, Aidan and Ridder, Ben (2006) 'Turbulent Times for Urban Nature: Conserving and Re-Inventing Nature in Australian Cities', Australian Zoologist 33(3): 306-14.

De Silvey, Caitlin (2006) 'Observed Decay: Telling Stories with Mutable Things', Journal of Material Culture 11(3): 318-38.

Descola, Phillipe and Pálsson, Gísli (eds) (1996) Nature and Society: Anthropological Perspectives. London: Routledge.

Dixon, G. (1986) ‘Dixon Farm', in Taroona Historical Group (ed.) Taroona 1808- 1986: Farm Lands to a Garden Suburb, pp. 298-301. Taroona: Taroona Historical Group.

Everett, Jim and Kimberley, Jonathan (2006) Meenamatta Water Country Discussion. Hobart: Bett Gallery.

Flannery, Tim (2002) “'The Day, The Land, The People”: Australia Day Address 2002', Sydney Conservatorium of Music, 23 January. URL (consulted 8 Feb.

2010): http://www.australiaday.com.au/whatson/australiadayaddress2.aspx?AddressID=12

Franklin, Adrian (2006) Animal Nation: The True Story of Animals and Australia. Sydney: University of New South Wales Press.

Gröning, Gert and Wolschke-Bulman, Joachim (2003) 'The Native Plant Enthusiasm: Ecological Panacea or Xenophobia?', Landscape Research 28(1): 75-88.

Hage, Ghassan (1998) White Nation: Fantasies of White Supremacy in a Multicultural Society. Sydney: Pluto Press.

Head, Lesley and Muir, Pat (2004) 'Nativeness, Invasiveness and Nation in Australian Plants', Geographical Review 94(2): 199-217. 
Head, Lesley and Muir, Pat (2005) 'Living with Trees - Perspectives from the Suburbs', in Michael Calver et al. (eds) Proceedings of the 6th National Conference of the Australian Forest History Society Inc, pp. 85-94. Rotterdam: Millpress.

Head, Lesley and Muir, Pat (2006) 'Suburban Life and the Boundaries of Nature: Resilience and Rupture in Australian Backyard Gardens', Transactions of the Institute of British Geography 31: 504-25.

Heynen, Nick, Kaika, Maria and Swyngedouw, Eric (eds) (2006) In the Nature of Cities: Urban Political Ecology and the Politics of Urban Metabolism. London: Routledge.

Hinchcliffe, Steve (2008) 'Reconstituting Nature Conservation: Toward a Careful Political Ecology', Geoforum 39(1): 88-97.

Hollander, Robyn (2006) 'Elections, Policy and the Media: Tasmania's Forests and the 2004 Federal Election', Australian Journal of Political Science 41(4): 569-84.

Ingold, Tim (2000) The Perception of the Environment. London: Routledge.

Jones, Owain and Cloke, Paul (2002) Tree Cultures. Oxford. Berg.

Larson, B.M.H. (2008) 'Entangled Biological, Cultural, and Linguistic Origins of the War on Invasive Species', in R.M. Frank et al. (eds) Body, Language and Mind, Vol. 2: Sociocultural Situatedness. Cognitive Linguistics Research 35.2, pp. 169-95. New York: Mouton de Gruyter.

Latour, Bruno (2004) Politics of Nature: How to Bring the Sciences into Democracy. Cambridge, MA: Harvard University Press.

Lester, Libby (2007) Giving Ground: Media and Environmental Conflict in Tasmania. Hobart: Quintus Publishing.

Lien, Marianne E. (2004) “'King of Fish" or "Feral Peril”: Tasmanian Atlantic Salmon and the Politics of Belonging', Environment and Planning D: Society and Space 23: 659-71.

Lien, Marianne E. (2007) 'Weeding Tasmanian Bush: Biomigration and Landscape Imagery', in Marianne E. Lien and Marit Melhuus (eds) Holding Worlds Together: Ethnographies of Knowing and Belonging, pp.103-21. Oxford: Berghahn.

Lines, William (2006) Patriots: Defending Australia's Natural Heritage. Brisbane: University of Queensland Press.

Low, Tim (1999) Feral Future. Hawthorn: Penguin Books.

Low, Tim (2003) The New Nature: Winners and Losers in Wild Australia. Hawthorn: Penguin Books.

Lund, Sarah (2007) 'Family Tracings: Global Gazes of Norwegian-American Genealogies', in Marianne E. Lien and Marit Melhuus (eds) Holding Worlds Together: Ethnographies of Knowing and Belonging, pp. 57-78. Oxford: Berghahn.

Milton, Kay (2000) 'Ducks out of Water: Nature Conservation as Boundary Maintenance', in John Knight (ed.) Natural Enemies: People-Wildlife Conflicts in Anthropological Perspective, pp. 229-46. London: Routledge.

Norwegian Biodiversity Information Centre (2007) 2007 Norwegian Black List (Ecological Risk Analysis of Alien Species). URL (consulted 11 Feb. 2010): http://www.artsdatabanken.no/Article.aspx?m=172\&amid=2581

NSW Department of Primary Industries (2008) 'Radiata Pine - The Remarkable Pine', /Primefact 646/, New South Wales Department of Primary Industry. URL (consulted 8 Feb.

2010): www.dpi.nsw.gov.au/primefacts; http://www.dpi.nsw.gov.au/primefacts

Parliament of Australia (2004) Turning Back the Tide - The Invasive Species Challenge. Report on the regulation, control and management of invasive species and the Environment Protection and Biodiversity Conservation Amendment (Invasive Species) Bill 2002. Environment, Communications, Information Technology and the Arts References Committee. 
Perera, Suvendrini (ed.) (2007) Our Patch: Enacting Australian Sovereignty Post-2001. Perth: Network Books.

Ridder, Ben (2007) 'Biodiversity versus Nature: Values in Conflict', unpublished PhD thesis, University of Tasmania.

Robbins, Paul (2004) 'Comparing Invasive Networks: Cultural and Political Biographies of Invasive Species', Geographical Review 94: 139-56.

Seddon, George (1997) Landprints: Reflections on Place and Landscape. Cambridge: Cambridge University Press.

Simberloff, Daniel (2005) 'Non-Native Species Do Threaten the Natural Environment', Journal of Agricultural and Environmental Ethics 18: 595-607.

Smout, T. Chris (2003) 'The Alien Species in 20th-Century Britain: Constructing a New Vermin', Landscape Research 18(1): 11-20.

Stratton, Jon (2007) 'Dying to Come to Australia: Asylum Seekers, Tourists and Death', in Suvendrini Perera (ed.) Our Patch: Enacting Australian Sovereignty Post-2001, pp. 107-97. Perth: Network Books.

Takacs, David (1996) The Idea of Biodiversity: Philosophies of Paradise. Baltimore, MD: Johns Hopkins University Press.

Tilley, Christopher (2006) 'Introduction; Identity, Place, Landscape and Heritage', Journal of Material Culture 11(1-2): 7-32.

Trigger, David (2008) 'Indigeneity, Ferality, and What "Belongs" in the Australian Bush: Aboriginal Responses to "Introduced" Animals and Plants in a Settler-Descendant Society', Journal of the Royal Anthropological Institute 14: 628-46.

Trigger, David and Mulcock, Jane (2005) ‘Forests as Spiritually Significant Places: Nature, Culture and “Belonging” in Australia', Australian Journal of Anthropology 16(3): 306-20.

Trigger, David et al. (2008) 'Ecological Restoration, Cultural Preferences and the Negotiation of "Nativeness" in Australia', Geoforum 39(3): 1273-83.

Turnbull, Malcolm and McGauran, Peter (2007) 'Forward', Journal of the Natural Heritage Trust 32 (special edition): 3.

Tyrrell, Ian (1999) True Gardens of the Gods: Californian-Australian Environmental Reform 1860-1930. Berkeley: University of California Press.

Van Driesche, Jason and Van Driesche, Roy (2000) Nature Out of Place: Biological Invasions in the Global Age. Washington, DC: Island Press.

Verran, Helen (2001) Science and an African Logic. Chicago: University of Chicago Press.

Whatmore, Sarah (2002) Hybrid Geographies: Natures, Cultures, Spaces. London: Sage.

Willadsen, Håvard (2009) 'Old Trees, New Realities: The Social Construction of Nature and the Remaking of Reality in the Struggle for Old-Growth Forests in Tasmania', unpublished Masters thesis, University of Oslo.

World Conservation Union (IUCN) (2000): 'IUCN 2000 Guidelines for the Prevention of Biodiversity Loss Caused by Alien Invasive Species'. URL:

intranet.iucn.org/. .

./IUCN_Guidelines_for_the_Prevention_of_Biodiversity_Loss_Caused_by_Alien_Invasive_Species.pdf

MARIANNE ELISABETH LIEN is Professor of Social Anthropology at the University of Oslo. She is the author of Marketing and Modernity (Berg, 1997) and co-editor of The Politics of Food (Berg, 2004) and Holding Worlds Together; Ethnographies of Knowing and Belonging (Berghahn, 2007). Marianne has published on food, consumption, globalization, markets and aquaculture. 
Her regional areas of interest are Scandinavia and Australia. More recently, she has been interested in biomigration, nature management and questions of human and non-human belonging. Address: Department of Social Anthropology, Postboks 1091, University of Oslo, 0317 Blindern, Norway. [email: m.e.lien@sai.uio.no]

AIDAN DAVISON is a Senior Lecturer in human geography in the School of Geography and Environmental Studies at the University of Tasmania, and is formerly Program Chair of Sustainable Development at Murdoch University. The author of Technology and the Contested Meanings of Sustainability (SUNY, 2001), Aidan has published on topics ranging from public perceptions of biotechnology to Australian urban environmentalism to education for sustainability. His research interests follow socio-cultural questions generated at the intersection of themes of technology, nature and sustainability. Address: School of Geography \& Environmental Studies, Bag 78, University of Tasmania, Hobart, Tasmania 7001, Australia. [email: Aidan.Davison@utas.edu.au] 